\section{A SCREENING METHOD FOR CELL WALL INHIBITORS USING A D-CYCLOSERINE HYPERSENSITIVE MUTANT}

\section{Takashi Kamogashira and Setsuko Takegata}

Tokushima Research Institute, Otsuka Pharmaceutical Co., Ltd.,

Kawauchi-cho, Tokushima 771-01, Japan

(Received for publication January 23, 1988)

Large numbers of antibiotics have been discovered in the past 40 years and many methods have been employed for discovery of novel antibiotics. One of them is the use of mutants that are highly sensitive to antibiotics. Recently $\beta$-lactam antibiotic-hypersensitive mutants of Escherichia coli ${ }^{12}$ and Pseudomonas aeruginosa ${ }^{2)}$ and an aminoglycoside-hypersensitive mutant of Klebsiella pneumoniae ${ }^{3)}$ have been used in screening for new antibiotics.

D-Cycloserine (DCS) has a broad antibacterial spectrum $^{4>}$ and acts on alanine racemase (EC 5.1.1.1) and D-alanine: D-alanine ligase (EC 6.3.2.4), which are involved in synthesis of the peptidoglycan layer of the cell wall in bacteria ${ }^{5,6)}$. The antibiotics MK641/MK6427,8) and alaphosphin $^{9)}$ also have a similar mechanism of action. Good synergy in bactericidal activity was demonstrated in the combinations between these antibiotics and $\beta$-lactam antibiotics ${ }^{10)}$. Therefore, DCS-type antibiotics are expected to be useful for clinical purposes, especially against $\beta$-lactam resistant bacteria. It is anticipated that a DCS-sensitive mutant should be useful in detecting minor and novel DCS-type antibiotics produced in fermentation broths. Based on this concept, we obtained a very sensitive and highly specific mutant to DCS derived from Staphylococcus aureus Newman.

In this paper we report the isolation and characterization of the DCS hypersensitive mutant $\mathrm{C}-33$, and its use in screening for antibiotics.

Induction and isolation of mutants were achieved by treating $S$. aureus Newman cells with $100 \mu \mathrm{g} / \mathrm{ml}$ of $N$-methyl- $N{ }^{\prime}$-nitro- $N$-nitrosoguanidine in $0.05 \mathrm{M}$ Tris-malate buffer $(\mathrm{pH} 6.0$ ) at $37^{\circ} \mathrm{C}$ for 15 minutes and then selecting in replicate nutrient agar (NA) plates with and without 1 $\mu \mathrm{g} / \mathrm{ml}$ of DCS. The colonies which did not grow on plates containing DCS were selected from a plate without DCS. Of the many DCSsensitive mutants cloned, strain C-33 was selected because of its high sensitivity and good growth at $37^{\circ} \mathrm{C}$. The mutant $\mathrm{C}-33$ showed similar growth to that of the parent one at $28^{\circ} \mathrm{C}$ and $42^{\circ} \mathrm{C}$ (data not shown). Therefore, S. aureus C-33 is not a ts-mutant.

The MIC of DCS against the mutant C-33 was $6 \mathrm{ng} / \mathrm{ml}$, indicating that it was 8,000 -fold more sensitive than the parent strain (MIC 50 $\mu \mathrm{g} / \mathrm{ml})$ to DCS. The inhibitory zones of DCS and other antibiotics against the C-33 and parent strains were determined by a conventional paperdise method using NA medium at $37^{\circ} \mathrm{C}$ (Table 1). The mutant C-33 showed specific sensitivity to DCS and was sensitive to $0.016 \mu \mathrm{g} / \mathrm{ml}$ of DCS, while the parent strain showed no inhibitory zone even at $1 \mu \mathrm{g} / \mathrm{ml}$. The C-33 and parent cells were equally sensitive to all other antibiotics and agents tested except Triton X-100.

To determine whether the antibiotics selected in the primary screen test by paper-disc assay were inhibitors of cell wall synthesis, the rates of incorporation of radioactive precursors into the acid-insoluble macromolecular fraction in S. aureus C-33 at various concentrations of DCS were measured as described previously ${ }^{11}$ ) (Table 2). The syntheses of DNA, RNA and protein, assayed by measuring the incorporation of $\left[{ }^{3} \mathrm{H}\right]$ thymidine, $\left[{ }^{3} \mathrm{H}\right]$ uridine and $\left[{ }^{3} \mathrm{H}\right]$ leucine, respectively, were scarcely affected by incubation for 30 minutes with DCS, even at a concentration of $1 \mu \mathrm{g} / \mathrm{ml}$ which induced a relatively large inhibitory zone. However at the low concentration of $0.01 \mu \mathrm{g} / \mathrm{ml}$, DCS prevented the incorporation of $N-\left[{ }^{14} \mathrm{C}\right]$ acetylglucosamine, a precursor of cell walls. Antibiotics other than cell wall inhibitors had no effect on the incorporation of $N-\left[{ }^{14} \mathrm{C}\right]$ acetylglucosamine in either $S$. aureus C-33 or $S$. aureus Newman (data not shown). Triton $X-100$, to which the mutant C-33 was more sensitive than the parent strain, also did not affect the incorporation of $N-\left[{ }^{14} \mathrm{C}\right]-$ acetylglucosamine into $\mathrm{C}-33$. These results showed that assay of incorporation of this radioactive precursor could also be used in the second test to detect inhibitors of cell wall synthesis.

The rates of incorporation of several radioactive precursors in the mutant $\mathrm{C}-33$ and the parent strain were compared (Fig. 1). Growing 
Table 1. Paper-disc assay using D-cycloserine (DCS)-hypersensitive mutant and its parent strain.

\begin{tabular}{|c|c|c|c|}
\hline \multirow{2}{*}{ Antibiotic } & \multirow{2}{*}{$\begin{array}{l}\text { Concentration } \\
(\mu \mathrm{g} / \mathrm{ml})\end{array}$} & \multicolumn{2}{|c|}{ Zone size $(\mathrm{mm})$} \\
\hline & & Parent & $\mathrm{C}-33$ \\
\hline \multirow[t]{4}{*}{ DCS } & 1 & - & 28.2 \\
\hline & 0.25 & - & 22.9 \\
\hline & 0.063 & - & 16.7 \\
\hline & 0.016 & - & 9.9 \\
\hline Fosfomycin & 10 & 18.2 & 18.2 \\
\hline Moenomycin & 10 & 13.5 & 15.7 \\
\hline Vancomycin & 100 & 14.7 & 15.3 \\
\hline Bacitracin* & & 10.4 & 10.1 \\
\hline Benzylpenicillin & 0.5 & 20.0 & 19.0 \\
\hline Cephalexin & 10 & 16.3 & 15.8 \\
\hline Gentiana violet & 25 & 14.4 & 15.4 \\
\hline Albocycline & 100 & 21.5 & 21.3 \\
\hline Glutamycin & 100 & 15.0 & 14.3 \\
\hline Mitomycin $\mathbf{C}$ & 4 & 15.5 & 15.7 \\
\hline Rifampicin & 1 & 18.5 & 19.4 \\
\hline Erythromycin* & & 22.4 & 24.2 \\
\hline Kitasamycin* & & 21.6 & 21.5 \\
\hline Novobiocin* & & 27.2 & 26.3 \\
\hline Mikamycin* & & 24.0 & 24.6 \\
\hline Lincomycin* & & 25.4 & 25.7 \\
\hline Chloramphenicol* & & 27.8 & 29.3 \\
\hline Tetracycline* & & 27.6 & 30.2 \\
\hline Kanamycin* & & 21.6 & 22.0 \\
\hline Streptomycin* & & 19.6 & 20.3 \\
\hline Nalidixic acid* & & 19.0 & 21.2 \\
\hline Furazolidon* & & 20.9 & 21.0 \\
\hline Colistin* & & - & - \\
\hline Polymyxin B* & & - & - \\
\hline $\mathrm{SDC}$ & 5,000 & 13.2 & 12.9 \\
\hline SDS & 5,000 & 14.3 & 14.8 \\
\hline Triton X-100 & 10,000 & - & 13.1 \\
\hline
\end{tabular}

Paper discs $(6.5 \mathrm{~mm}$ in diameter) were used.

* Commercial discs from Showa Yakuhin Kako Co., Ltd.

SDC: Sodium dodecyl chloride.

-: No inhibitory zone was detected.

Table 2. Effect of D-cycloserine (DCS) on the incorporation of radioactive precursors into the acidinsoluble macromolecular fraction in Staphylococcus aureus C-33.

\begin{tabular}{ccccc}
\hline \multirow{2}{*}{$\begin{array}{c}\text { DCS conc } \\
(\mu \mathrm{g} / \mathrm{ml})\end{array}$} & \multicolumn{4}{c}{ Incorporation $(\%)$} \\
\cline { 2 - 5 } & {$\left[{ }^{14} \mathrm{C}\right]$ GlcNAc } & {$\left[{ }^{3} \mathrm{H}\right]$ Thd } & {$\left[{ }^{3} \mathrm{H}\right]$ Urd } & {$\left[{ }^{3} \mathrm{H}\right]$ Leu } \\
\hline 0 & 100 & 100 & 100 & 100 \\
0.01 & 63 & 106 & 105 & 102 \\
0.1 & 39 & 105 & 102 & 100 \\
1 & 19 & 95 & 94 & 96 \\
\hline
\end{tabular}

Abbreviations: $\left[{ }^{14} \mathrm{C}\right]$ GlcNAc, $N-\left[{ }^{14} \mathrm{C}\right]$ Acetylglucosamine; $\left[{ }^{3} \mathrm{H}\right] \mathrm{Thd},\left[{ }^{3} \mathrm{H}\right]$ thymidine; $\left[{ }^{3} \mathrm{H}\right] \mathrm{Urd},\left[{ }^{3} \mathrm{H}\right]-$ uridine; $\left[{ }^{3} \mathrm{H}\right] \mathrm{Leu},\left[{ }^{3} \mathrm{H}\right]$ leucine. 
Fig. 1. Incorporations of $N-\left[{ }^{14} \mathrm{C}\right]$ acetylglucosamine (a), $\mathrm{L}-\left[{ }^{14} \mathrm{C}\right]$ alanine (b), and $\mathrm{D}-\left[{ }^{14} \mathrm{C}\right]$ alanine (c) into the acid-insoluble macromolecular fraction of growing cells of Staphylococcus aureus Newman and C-33.

OS. aureus Newman, S. aureus C-33.

(a)

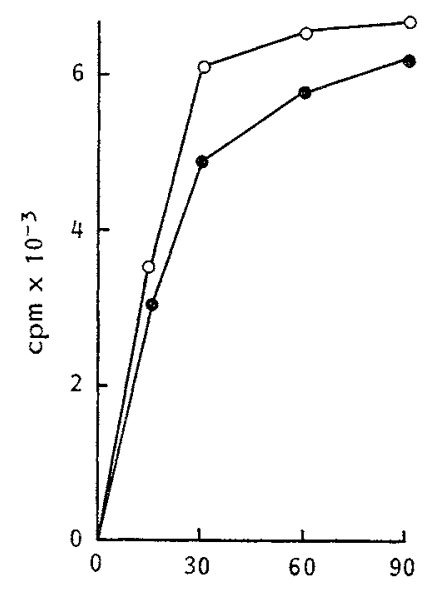

(b)

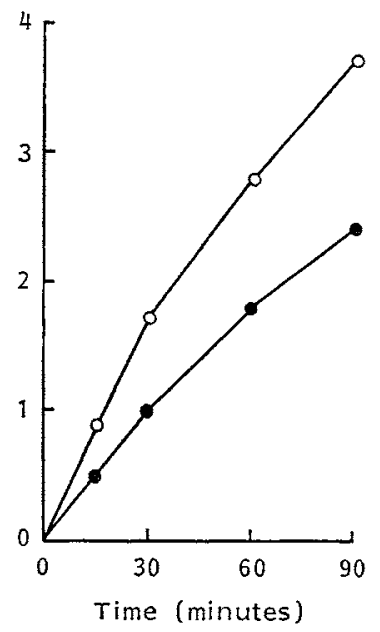

(c)

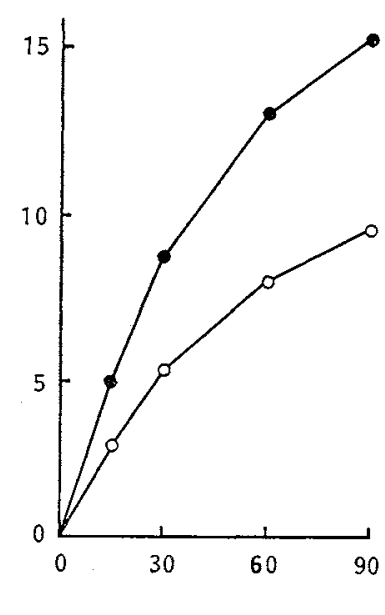

cells of $S$. aureus $\mathrm{C}-33$ showed higher incorporation of $\mathrm{D}-\left[{ }^{14} \mathrm{C}\right]$ alanine into the acid-insoluble macromolecular fraction than S. aureus Newman cells while showed less incorporation of $N-\left[{ }^{14} \mathrm{C}\right]-$ acetylglucosamine and ${ }_{L}-\left[{ }^{[4} \mathrm{C}\right]$ alanine. This seems to show that one of the mechanisms of sensitivity of the mutant to DCS could be a change in the $\mathrm{D}$-alanine transport system.

By screening about 8,000 soil isolates, including bacteria, fungi and actinomycetes, one antibiotic, TA-243 ${ }^{12}$, was discovered, and three known antibiotics, $\mathrm{DCS}^{4)}, \quad O$-carbamyl-Dserine $^{133}$ and FR-900148 ${ }^{14)}$, were identified.

DCS was isolated from cultures of a wide variety of soil isolates, of which Streptomyces was the commonest, accounting for $0.5 \%$ of the total. DCS was also isolated from cultures of three rare actinomycetes and one Pseudomonas sp.

TA-243 produced by Streptomyces griseofuscus OFR 1388, a new antibiotic discovered by this screening procedure, is a novel inhibitor of cell wall synthesis. TA-243 was actively transported into bacterial cells by peptide transport system and was subsequently hydrolyzed by intracellular aminopeptidases to yield aminooxysuccinic acid. Its primary intracellular target site was alanine racemase (manuscript in preparation).

The strain C-33 is the first example of DCShypersensitive mutants. The above results in- dicate that it is a useful tool in screening work for new cell wall inhibitors.

\section{Acknowledgments}

The authors thank many colleagues for their helpful assistance in screening tests.

\section{Reference}

1) Aoki, H.; K. Kunugita, J. Hosoda \& H. IMANAKA: Screening of new and novel $\beta$-lactam antibiotics. Jpn. J. Antibiotics 30 (Suppl.): S-207 S-217, 1977

2) Kitano, K.; K. NARA \& Y. NAKaO: Screening for $\beta$-lactam antibiotics using a mutant of Pseudomonas aeruginosa. Jpn. J. Antibiotics 30 (Suppl.): S-239 S-245, 1977

3) Numata, K.; H. Yamamoto, M. Hatori, T. MIYAKI \& H. KAWAGUCHI: Isolation of an aminoglycoside hypersensitive mutant and its application in screening. J. Antibiotics 39: $994 \sim 1000,1986$

4) Harris, D. A.; M. Ruger, M. A. Reagan, F. J. Wolf, R. L. PECK, H. Wallick \& H. B. WoODRUFF: Discovery, development, and antimicrobial properties of D-4-amino-3-isoxazolidone (oxamycin), a new antibiotic produced by Streptomyces garyphalus n. sp. Antibiot. Chemother. 5: 183 190, 1955

5) Lambert, M. P.\& F. C. Neuhaus: Mechanism of D-cycloserine action: Alanine racemase from Escherichia coli W. J. Bacteriol. 110: 978 987, 
1972

6) Neuhaus, F. C. \& J. L. LyNCH: The enzymatic synthesis of D-alanyl-D-alanine. III. On the inhibition of $\mathrm{D}$-alanyl-D-alanine synthetase by the antibiotic D-cycloserine. Biochemistry 3: $471 \sim 480,1964$

7) KaHAN, F. M. \& H. KRopp: MK641/MK642 a fixed-ratio combination antimicrobial. 1 Rationale: The sequential blockade of bacterial cell-wall biosynthesis. Program and Abstracts of the 15th Intersci. Conf. on Antimicrob. Agents Chemother., No. 100, Washington, D. C., Sept. $24 \sim 26,1975$

8) KaHAN, F. M.; H. Kropp, H. R. ONISHI \& D. P. JACoBus: MK641/MK642 a fixed-ratio combination antimicrobial. 4 Advantages over the FA/CS prototype. Program and Abstracts of the 15th Intersci. Conf. on Antimicrob. Agents Chemother., No. 103, Washington, D. C., Sept. $24 \sim 26,1975$

9) Atherton, F. R.; M. J. Hali, C. H. Hassall, R. W. LAmbert, W. J. Lloyd \& P.S. RingROSE: Phosphonopeptides as antibacterial agents: Mechanism of action of alaphosphin. Antimicrob. Agents Chemother. 15: 696 705, 1979

10) Allen, J. G.; F. R. Atherton, M. J. Hall, C.
H. Hassall, S. W. Holmes, R. W. Lambert, L. J. Nisbet \& P.S. Ringrose: Phosphonopeptides as antibacterial agents: Alaphosphin and related phosphonopeptides. Antimicrob. Agents Chemother. 15: 684 695, 1979

11) Kamogashira, T.; T. Nishida \& M. Sugawara: A new glycopeptide antibiotic, OA-7653, produced by Streptomyces hygroscopicus subsp. hiwasaensis. Agric. Biol. Chem. 47: 499 506, 1983

12) Sugawara, M.; A. Kato, K. Matsui, Y. Kaise, M. Kurozumi \& T. KaMoGashira: A new cell wall inhibitor, TA-243, produced by Streptomyces griseofuscus OFR 1388. Abstracts Papers of Annual Meeting of the Agricultural Chemical Society of Japan, No. 1U-1, p. 299, Tokyo, Apr. $1 \sim 4,1984$

13) OKami, Y.; K. Maeda, H. Kondo, T. Tanaka \& H. UMEZAWA: A streptomyces producing O-carbamyl-D-serine. J. Antibiotics, Ser. A 15: $147 \sim 151,1962$

14) Kuroda, Y.; M. Okuhara, T. Goto, M. YamaSHITA, E. IGUCHI, M. KoHSAKA, H. AOKI \& H. IMANAKA: FR-900148, a new antibiotic. I. Taxonomy, fermentation, isolation and characterization. J. Antibiotics 33: 259 266, 1980 